University of Rhode Island

DigitalCommons@URI

Open Access Master's Theses

1992

\title{
Impacts of the Route 25 Bypass on the Cranberry Highway in Wareham, Massachusetts
}

Paige Elizabeth Holland

University of Rhode Island

Follow this and additional works at: https://digitalcommons.uri.edu/theses

\section{Recommended Citation}

Holland, Paige Elizabeth, "Impacts of the Route 25 Bypass on the Cranberry Highway in Wareham, Massachusetts" (1992). Open Access Master's Theses. Paper 757.

https://digitalcommons.uri.edu/theses/757

This Thesis is brought to you for free and open access by DigitalCommons@URI. It has been accepted for inclusion in Open Access Master's Theses by an authorized administrator of DigitalCommons@URI. For more information, please contact digitalcommons-group@uri.edu. 
IMPACTS OF THE ROUTE 25 BYPASS ON THE CRANBERRY HIGHWAY IN WAREHAM, MASSACHUSETTS

BY

PAIGE ELIZABETH HOLLAND

\author{
A RESEARCH PROJECT SUBMITTED IN \\ PARTIAL FULFILLMENT OF THE REQUIREMENTS \\ FOR THE DEGREE OF MASTER OF \\ COMMUNITY PLANNING
}

UNIVERSITY OF RHODE ISLAND

1992 


\section{MASTER OF COMMUNITY PLANNING RESEARCH PROJECT \\ OF}

\section{PAIGE ELIZABETH HOLLAND}

Approved:

Major Professor

Acknowledged:

Director

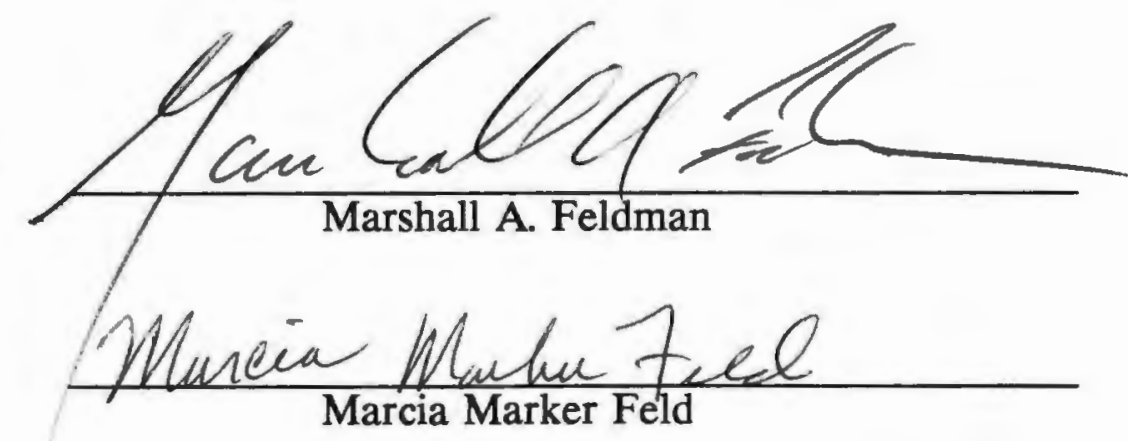




\begin{abstract}
The Cranberry Highway runs through Wareham, Massachusetts as Route 6/28 from the end of Interstate 495. Prior to 1987 it was the only route onto Cape Cod from the west and northwest and had an average daily traffic volume of approximately 38,000 year-round. On Saturdays and Sundays from May through August the average daily traffic would exceed 60,000 cars, creating severe congestion along the Cranberry Highway. On August 11, 1987, an extension to Route 25 from the end of Route 495 to the Bourne bridge opened, effectively bypassing the Cranberry Highway. Since the opening of this route, traffic has declined over fifty percent.

This study examines the effects of the Route 25 bypass on the Cranberry Highway. Specifically, this research focuses on measuring impacts on traffic, business, and land values along the Cranberry Highway.
\end{abstract}




\section{ACKNOWLEDGEMENTS}

There are a number of people I wish to thank for their assistance with this project. First, I wish to express my appreciation to Dr. Marshall A. Feldman for all the advice offered and his patience with my unique timeline. Dr. Feldman's knowledge and ideas provided me with insight that made this report a better

document. I would also like to thank Dr. Farhad Atash for his assistance and guidance throughout the past year and a half.

Special thanks to the loved ones in my life. Without my family, friends, and Jay, I never would have made it through the past two years. You all mean the world to me. 
ABSTRACT

ACKNOWLEDGEMENTS $\quad$ iii

CHAPTER ONE-INTRODUCTION

Problem Statement $\quad 2$

The Study Area 3

The Control Area 6

Comparison of study areas $\quad 8$

Significance $\quad 9$

Objectives 9

CHAPTER TWO-RELATED LITERATURE 10

$\begin{array}{ll}\text { Case Studies } & 12\end{array}$

$\begin{array}{ll}\text { CHAPTER THREE-TRAFFIC } & 17\end{array}$

Introduction $\quad 18$

Data Sources 20

Analysis 20

Summary $\quad 22$

CHAPTER FOUR-BUSINESS

Introduction $\quad 26$

Data Sources $\quad 29$

Analysis $\quad 31$

Summary 33

CHAPTER FIVE-LAND VALUE

Introduction $\quad 36$

Methods and Procedures $\quad 37$

Analysis $\quad 38$

$\begin{array}{ll}\text { Summary } & 40\end{array}$

CHAPTER SIX-CONCLUSION $\quad 41$

Suggestions for further research $\quad 42$

Summary 43

$\begin{array}{ll}\text { APPENDIX } & 45\end{array}$

$\begin{array}{lr}\text { REFERENCES } & 48\end{array}$ 


\section{LIST OF TABLES}

Table $\quad \underline{\text { Title }}$

Page

3-1 Traffic Counts on the Cranberry Highway

Before and After Bypass Opening

3-2 Wareham and Yarmouth Traffic Counts Route 6/28 at Bourne Town Line and Route 28 at Barnstable Town Line, 1986-1989

4-1 Gain or Loss in Retail Sales in Bypassed Towns, by Population Size

4-2 Number of Bypassed Towns Having Gains and Losses in Retail Sales for Highway and Non Highway-Oriented Business, by Population Size

4-3 Highway-Oriented Businesses on the Cranberry Highway and Route 28 in Yarmouth, 1984-1992 


\section{LIST OF FIGURES}

Figure Title Page

1-1 Map of Southern New England 4

1-2 Map of Highway Network in the Vicinity of

Wareham including the Route 25 Bypass 5

1-3 Map of Yarmouth's location on Cape Cod 7

3-1 Comparison of Traffic Counts on the Cranberry

Highway and Route 28 in Yarmouth, 1986-1989 23

5-1 Property Sales in Wareham and Yarmouth Average

Price Per Square Foot, 1986-1990 
CHAPTER ONE INTRODUCTION 


\section{CHAPTER ONE}

INTRODUCTION

\section{Problem Statement}

Many of the main routes leading into and through cities and towns are characterized by heavy commercial development and congestion. For certain types of businesses--gas stations, motels, eating establishments, and gift shops--major highways are preferred locations. Many roadside areas have evolved into commercial strip developments, which frequently occupy only the land adjacent to the road with the area behind them remaining undeveloped. This poorly planned, formless development of roadside areas not only harms the general attractiveness of the countryside, but creates traffic congestion and increases the accident hazard on the highway. To overcome such problems--to remove from local streets through traffic that does not wish to stop or be delayed--bypass routes have been provided in many areas.

The purpose of this research project is to assess the effects of the Route 25 bypass on Wareham's commercial strip along the Cranberry Highway. The project will examine and measure impacts on traffic, business, and land values along the Cranberry Highway. 


\section{The Study Area.}

Wareham, Massachusetts, called "The Gateway to Cape Cod", is located east of the Bourne Bridge one hour from Providence, Boston, and Worcester (Figure 1-1). The Cranberry Highway runs through Wareham as Route 6/28 from the end of Interstate 495 (Figure 1-2). Prior to 1987 it was the only route onto Cape Cod from the west and northwest. The highway is a four-lane arterial with unlimited access and seven major intersections with traffic lights. In 1985, prior to the bypass completion, the average daily traffic on the Cranberry Highway was 30,000 cars yearround with a peak of approximately 65,000 cars per day during the summer months. During the peak season times traffic was severely congested, creating the need for a more effective route onto Cape Cod.

In 1987, Route 25 was extended from the end of Route 495 to the Bourne Bridge, effectively bypassing the Cranberry Highway. Since the route was constructed, traffic on the Cranberry Highway has declined by at least fifty percent. This study examines the effects of Route 25 on the Cranberry Highway. Specifically, this research focuses on measuring impacts on traffic, business, and land values along the Cranberry Highway. A control area is used to ensure that the effects of the bypass can be separated out from other changes in the area. It is common knowledge that marked variations in business conditions occur from time to time due to such factors as seasonal characteristics or the state of the economy. To control for these factors a stretch of highway in Yarmouth is used as a control. 
FIGURE 1-1

SOUTHERN NEW ENGLAND REGION

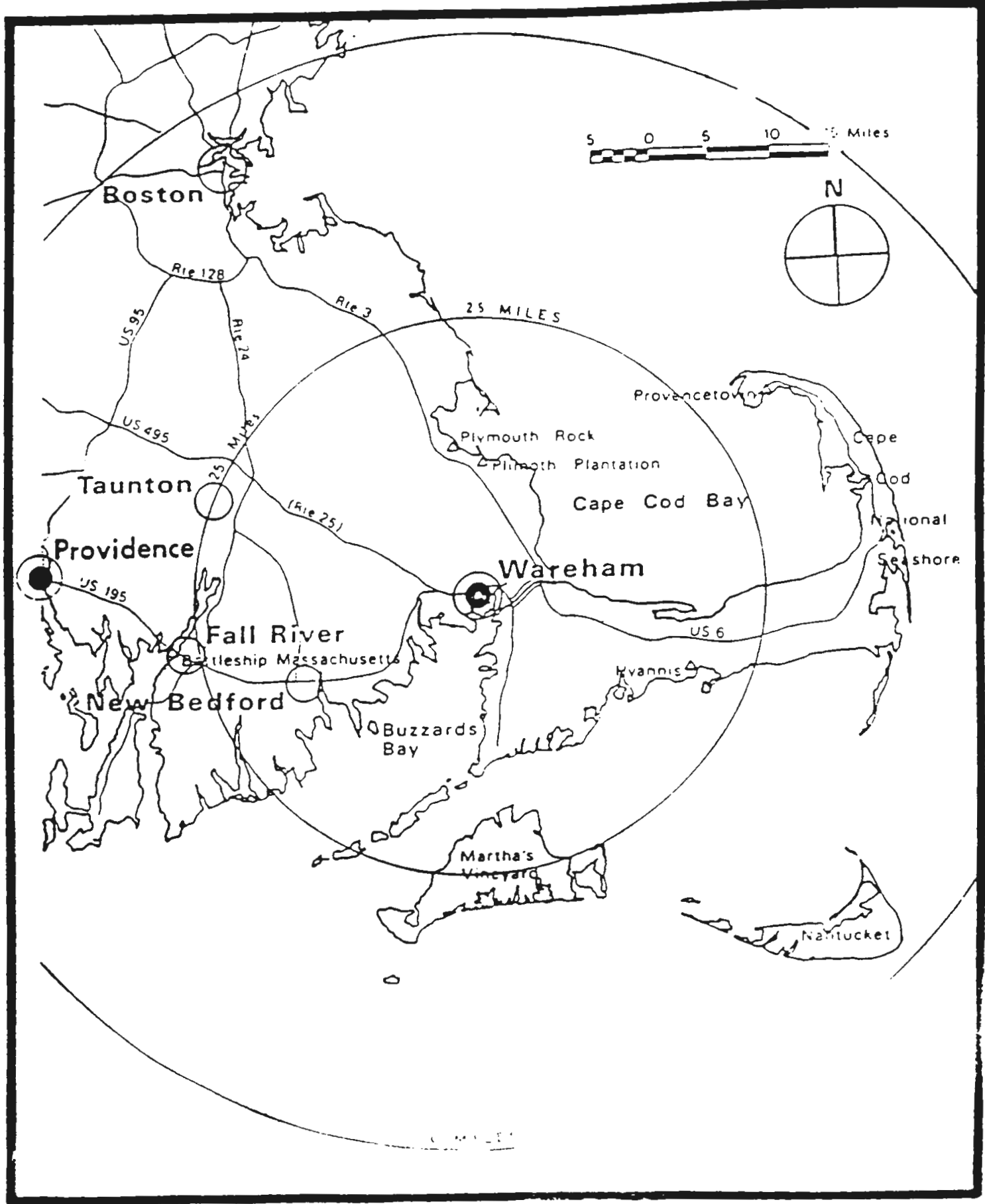

Source: Wareham Community Development Department (1985). 
FIGURE 1-2

HIGHWAY NETWORK IN THE VICINITY OF WAREHAM INCLUDING THE ROUTE 25 BYPASS

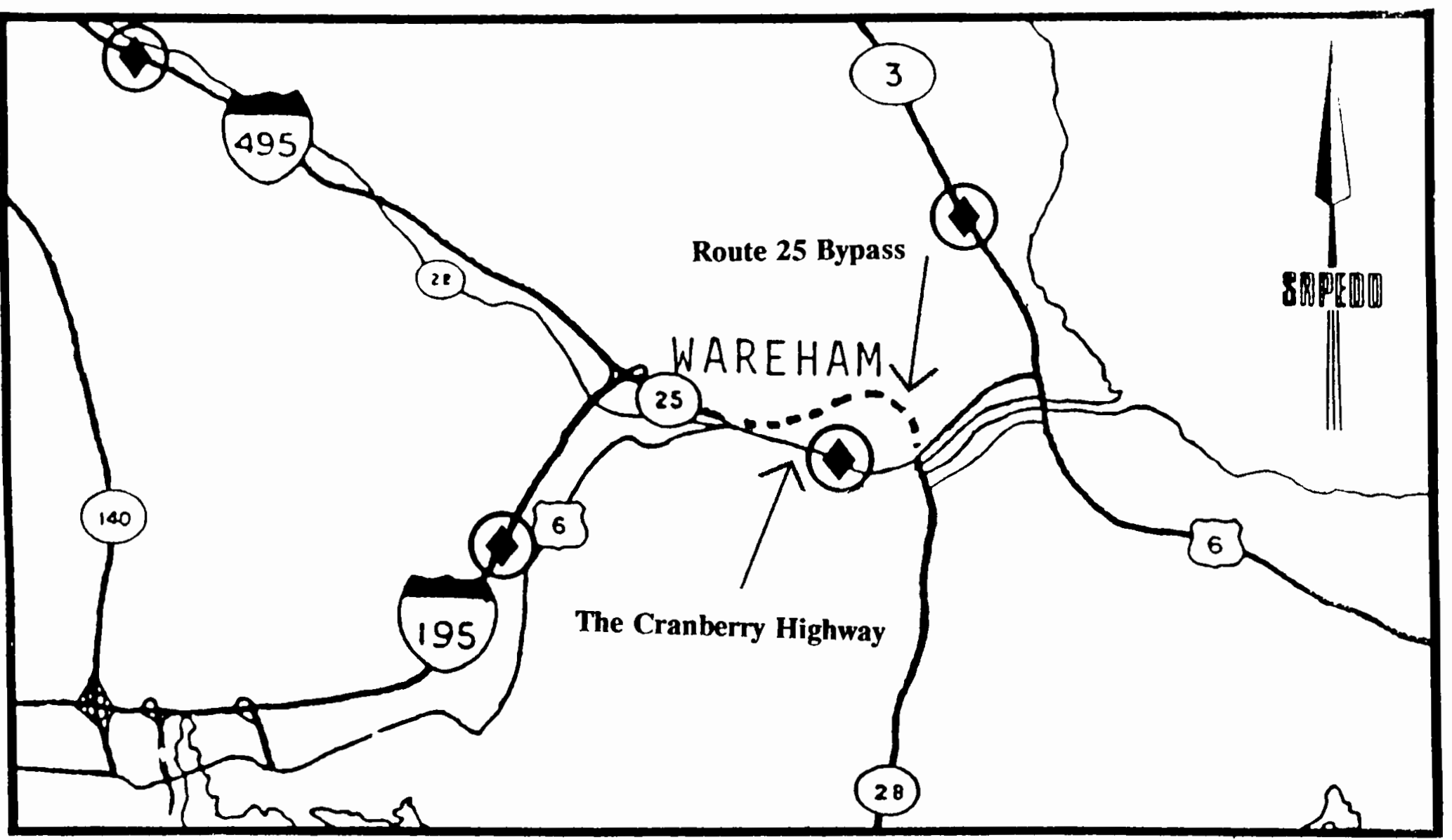

Source: Wareham Community Development Department (1985). 


\section{The Control Area.}

Route 28 in Yarmouth was chosen to be the control area for this study. The approximate length of the Cranberry Highway study area, three miles, was measured from the Barnstable/Yarmouth town line and is considered the study area for this report.

Yarmouth is located in the middle of Cape Cod, bordered by Barnstable to the east and Dennis to the west. The town is approximately 65 miles southwest of Provincetown and 23 miles east of the Cape Cod Canal (see Figure 1-3). This area is one of the most popular vacation spots for tourists on Cape Cod. Having a yearround population of 21,174 people, Yarmouth's summer population swells to approximately 56,000 people.

Three major highways serve this area. Route 6 is a limited access highway running from the Sagamore Bridge to Provincetown. Route 6A, an unlimited access road that was bypassed by Route 6 many years ago, is not as widely used as either Route 6 or Route 28 . Route 28 is an unlimited access highway that serves both local traffic and through traffic. In the summer through travel on Route 28 is impractical because high traffic congestion causes major delays. During the winter months when traffic congestion is not a major problem, Route 28 is frequently used for through travel throughout the Cape. As in Wareham, Route 28 in Yarmouth is a four lane road with intensive commercial development. This area was chosen as the control for this study because Route 28 in Yarmouth has not been subjected to any major 
FIGURE 1-3

YARMOUTH'S LOCATION ON CAPE COD

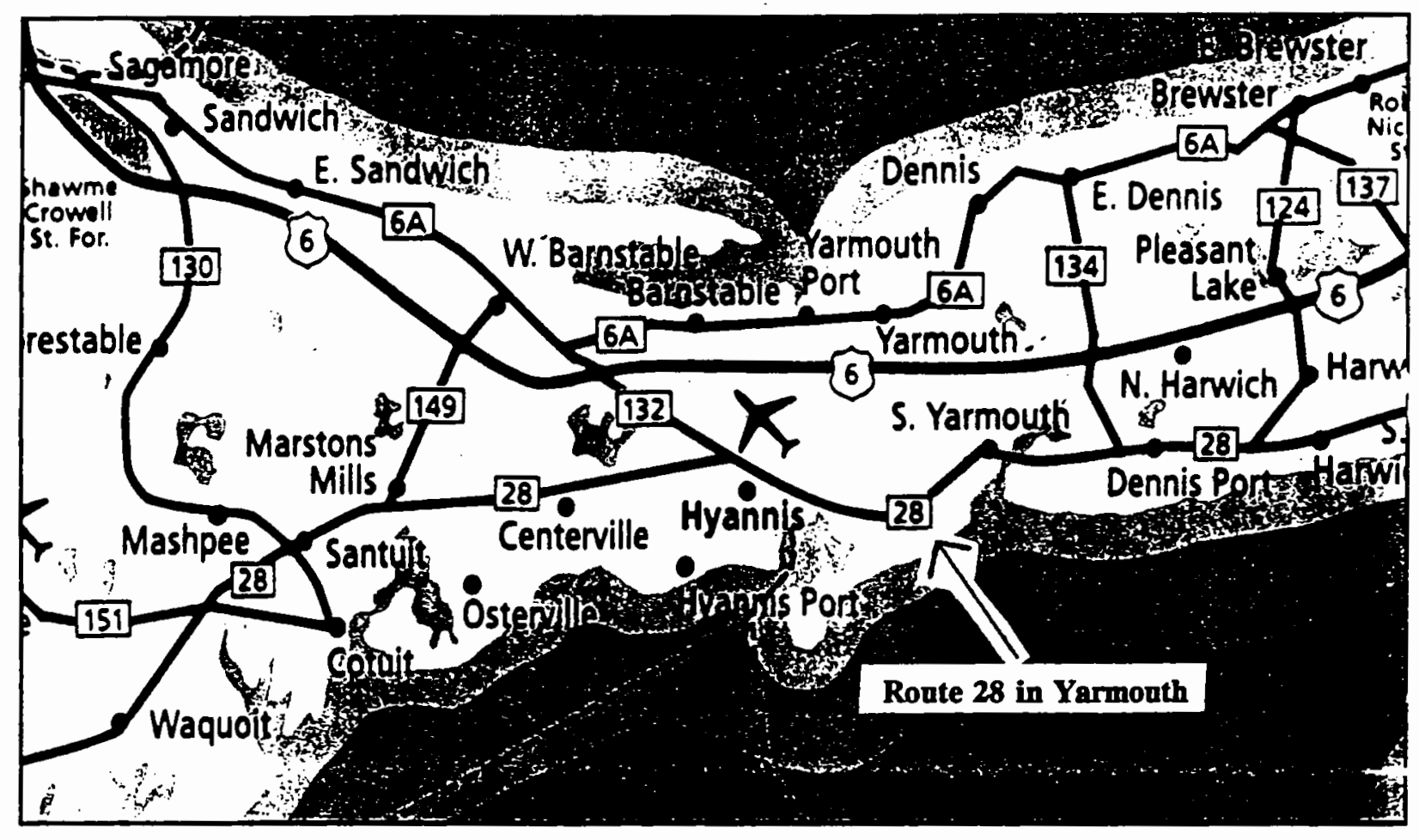

Source: New England Telephone (1991). 
changes in its highway service in recent years and there are enough commonalities between the two areas to make a comparison appropriate.

\section{Comparison of the two study areas}

Route 28 in Yarmouth and Route 6/28 in Wareham are four lane, unlimited access highways with numerous traffic signals. Prior to the bypass, both roads catered extensively to tourist traffic with the heaviest traffic flow occurring during the summer months. As a result, many of the businesses in the two areas were tourist or through-traffic oriented with high density, strip commercial development. Large numbers of motels, fast food restaurants, amusement and recreation facilities, and souvenir or gift shops occupied lots along the highways.

There are also some inherent differences between the two areas that may affect the results. Most important is the character of the two areas. Historically, Wareham has rarely been a destination for tourists. Most travellers heading to the Cape did not plan to stop in Wareham as part of their vacation itinerary. If a traveller stopped in Wareham, it was usually a quick stop at a convenience store or gas station along the Cranberry Highway. As a result, the businesses along the highway catered mainly to through traffic. Yarmouth, however, has always been a destination for travellers. Summer residents demand different types of services such as family restaurants, recreation and amusement facilities, and motels. Also, prior to the bypass there was no alternative to travelling on the Cranberry Highway when coming from the west on Routes 495 or 195 . In Yarmouth there are several roads 
to choose from, such as Route 6, Route $6 \mathrm{~A}$, or Route 28 . These differences may influence the study's outcome and the findings must take these differences into account.

\section{Significance}

There are many concerns about bypasses and their impacts on businesses. Business owners often oppose bypasses for fear of negative consequences. In many communities business owners are very influential and may use their power to dissuade officials from approving a bypass. As discussed in the next chapter, the fear of negative impacts on business is not founded in solid knowledge. Unfortunately, most people are unaware that bypasses often benefit businesses, and as a result bypasses are slow in receiving support from politicians, business owners, and residents.

Observation and evaluation of changes on the Cranberry Highway as a result of the bypass will provide information on changes that may be expected in other communities as highway improvements occur. This information can be used by town and state officials when deciding on a highway improvement such as bypasses.

\section{Objectives}

The goal of this study is to assess the impacts of the bypass on the Cranberry Highway. Specifically, the study will examine the bypass' impacts on: (1) traffic, (2) the number and types of businesses, and (3) land values. 
CHAPTER TWO RELATED LITERATURE 


\section{CHAPTER TWO \\ RELATED LITERATURE}

The common assumption that a bypassed road will suffer negative impacts is generally not true. In fact, most research studies find the contrary.

Bypass routes are advantageous because they can reduce traffic congestion and increase safety, but many fear adverse effects on businesses in the bypassed area because traffic volumes and business activities are closely related. This fear is often either unfounded or greatly exaggerated. Garrison and Marts (1958a: 23) state that "reorientation of through transportation facilities from the main street of a town reduces congestion and makes the town a more desirable place to stop". Congested traffic, such as the conditions on the Cranberry Highway prior to the bypass construction, can be just as harmful to business as a lack of traffic. Removal of through traffic from heavily travelled streets has, in many cases, brought substantial gains in business activity (U.S. Department of Commerce, Office of Research and Development 1964a: 89). Also, businesses are seldom completely dependent upon tourists. After the construction of a bypass there is usually a shift towards local trade which did not previously exist because community residents avoided the commercial strip due to traffic congestion. Many businesses that provide services to non-local residents serve local residents at the same time or during the off-season (Johnson, Obcrmiller, and Radtre 1989: 152). This was true in Wareham. Prior to the bypass, local residents would avoid Cranberry Highway, especially during the summer. When the bypass was completed, businesses experienced an increase in local patronage 
which compensated for the loss of through traffic. In fact, serving local residents is preferable because they require services for the entire year rather than just the summer months. The pattern is common:

Of the seventy-six bypassed areas for which information about retail trade activity is available, fifty experienced either a greater increase or smaller decrease than occurred in a comparable area that was not bypassed (U.S. Department of Commerce, Office of Research and Development 1964b: 92).

This does not imply some businesses do not suffer as a result of a bypass. Businesses are affected by a bypass in proportion to their dependence on through traffic. After the Route 25 bypass, the businesses that suffered the most losses were generally motels and souvenir shops (Fales 1989: 31). The majority of businesses, including gas stations and restaurants which traditionally cater to through traffic, were positively affected by the bypass because of the beneficial shift to local trade.

\section{Case Studies}

The following section features a sampling of many reports that address the impacts of highway bypasses on United States cities and towns. The purpose of discussing these reports is to highlight the findings of previously written bypass studies and to allow for an understanding of the changes that commonly occur as a result of a highway improvement or bypass.

American Fork, Utah. This study analyzed the changes in community attitudes and the growth or decline of business activities after the opening of the Interstate 15 bypass. Spanish Fork and Provo, both towns of similar characteristics located in the same county, were used as control areas. Findings of the study 
indicate that the expected losses from the bypass never occurred. On the contrary, property values, construction activity, and employment increased after the bypass (Utah State University 1968).

Circleville, Piqua, and St. Clairsville, Ohio. This study determined the effects of bypassing these Ohio cities. Data were collected on most businesses in the area, both transient oriented and locally oriented. Other sources of information included an origin and destination survey, a parking survey, traffic counts, and land value data from land assessment records. The general conclusion was that highway bypasses around population centers may alleviate congestion and greatly improve the traffic flow, but small adverse economic changes may also result (Ohio Department of Highways 1966).

Conroe, Texas. The following findings were arrived at from a study of the Interstate Highway 45 bypass of Conroe, Texas: (1) The study-area land values were increased considerably. (2) The highway has had a significant positive influence on land use changes. (3) Business activity has substantially increased. (4) The travel pattern of highway users has significantly changed. Most of the through traffic is successfully routed around Conroe. (5) Conroe and its county, Montgomery, have shown economic growth since the highway construction (Buffington 1967).

Fairfield. California. When U.S. 40 completely bypassed the town in 1949, traffic on the old route was riduced by approximately eighty percent. Several years later the amount of traffic on the old route remained much lower than it was prior to the bypass, which improved the desirability of business locations along the old 
route. The businesses along the old route are "enjoying higher business returns from the increased patronage of local customers without the congestion of through traffic" (Young 1951).

Faribault. Minnesota. This study determined the effects of the bypass on the total gross sales of the downtown area of Faribault. Four conclusions were drawn: (1) In the years since the bypass, the dollar volume of all retail sales has continued to rise. (2) In some instances, 6,000 cars a day bypassing the CBD has proven beneficial. (3) Gasoline sales have risen. (4) New business enterprises have emerged, especially at intersections or along the most travelled routes connecting the bypass with the downtown business district (Vockrodt 1967).

Folsom. California. In 1949, the realignment of U.S. Highway 50 resulted in the bypassing of Folsom. The California Division of Highways found that business conditions in Folsom varied only slightly from changed business conditions in Sacramento County as a whole. In spite of the diversion of through traffic from the town, the expected loss of business never occurred. In fact, retail sales by cafes, bars, and service stations increased in Folsom slightly more than in the county (Garrison and Marts 1958a: 28).

Marysville. Washington. When U.S. Highway 99 was improved in 1954, through travellers were no longer required to pass through Marysville. Rather than proving detrimental, access within and around the town was improved. The reorientation of through traffic resulted in more local people shopping than prior to the opening of the bypass. Sixty percent of the surveyed businesses experienced an 
increase in local patronage. After the bypass, Marysville experienced an increase in land values in the bypassed area (Garrison and Marts 1958b).

Rolla, Missouri. This town was bypassed by U.S. Highway 66 in 1966. The findings of the study indicated that sales volumes of cafes and bars had decreased by $12.5 \%$ and service stations by $8.7 \%$ since the opening of the bypass. However, the sales volumes in these categories had declined by as much or more in the two years prior to the bypass opening. The Missouri State Highway Department cautioned that the decline in these categories must be interpreted carefully to avoid placing false blame on the bypass. In general, the report found that "the new bypass had a favorable effect on Rolla's overall economy" (Garrison and Marts 1958b: 31)

Tyndall. South Dakota. A study of the economic effects of the South Dakota Highway 50 bypass on the town of Tyndall indicated that sales for the town as a whole were not affected by the existence of a bypass route. The non highwayoriented type of business did reasonably well and were unaffected or affected positively by the bypass route. Adverse effects were noted on highway-oriented businesses (service stations, restaurants, taverns, and motels). The traffic pattern, as expected, changed noticeably. Removing "through" traffic from Tyndall's business district resulted in less traffic congestion and greater traffic safety along the old route through town (Jorgenson 1968).

West Sacramento, California. The relocation of two highways, U.S. 40 and 99W resulted in the bypassing of West Sacramento. In this case, bars, cafes, and services stations, all typically highway-oriented businesses, experienced an increase 
in sales after the bypass. Also, several new motels were opened after the bypass construction and the availability of motel units increased thirty five percent. "This study conclusively shows that the highway merchant need not expect business decline and capital depreciation as a universal aftermath of traffic diversion" (Smith 1957: 49). 


\section{CHAPTER THREE}

TRAFFIC 


\section{CHAPTER THREE}

TRAFFIC

Introduction

Strip development along major arterials has the potential to create numerous conflicts. Poor access and high congestion on a roadway tend to reduce its carrying capacity, cause high levels of motorist discomfort and accidents, and decrease levels of traffic service (Stover and Koepke 1988a: 2). The Cranberry Highway, prior to the construction of the Route 25 bypass, was plagued by all of the above-mentioned problems. These problems stemmed from unplanned and unlimited access and an overburden on the level of service for which the road was designed. Before completion of the bypass, the highway carried the combined traffic loads of Routes I-195 (four lanes), Route 25 (six lanes), U.S. 6 (two lanes), and Route 28 (two lanes) as they converged at the Cranberry Highway in Wareham and Bourne en-route to the Bourne Bridge. Effectively the converging highways were squeezing eastbound traffic from seven one-way lanes into the Cranberry Highway's two eastbound lanes (Wareham Community Development Authority 1985: 13). In addition to problems related to high traffic counts, highway-oriented commercial development flourished, contributing to congestion.

Transportation and land development are inextricably bound: land development cannot occur without transportation and transportation facilities, such as the Cranberry Highway, serve no economic purpose without development. In transportation, the goal is to provide for the efficient movement of people and goods 
between land uses. The goal of land development is usually to achieve a profitable end. The two are so bound together that conflicts between them are often the result (Davey, Holland, and Tenreiro 1990: 6-1).

A major conflict existed between the uses of the Cranberry Highway before the opening of Route 25. Through travellers wanted to reach their destination in the fastest and most efficient manner possible, while local traffic wanted to use the road for other purposes such as shopping or local travel. As a result, further conflict between land uses (e.g. businesses) occurred because some of the businesses on the highway benefitted from the high amounts of through traffic, while others were harmed because of a lack of accessibility to local traffic. Upon completion of the bypass, purely through traffic was removed, the remaining traffic on the Cranberry Highway was there by choice, and most of the conflict was eliminated. The geometrics of the road no longer had to be geared to the efficient movement of traffic (Southeastern Regional Planning and Economic District 1985: 25).

Studies written prior to opening of the bypass, by the town of Wareham and the Southeastern Regional Planning and Economic Development District, supported the idea that most traffic after the bypass completion would be local. One traffic study (Southeastern Massachusetts Metropolitan Planning Organization 1985) predicted over seventy percent of the traffic found on the Cranberry Highway prior to the construction of Route 25 would be re-routed onto the new road. The study also predicted that most of the travel on the Cranberry Highway after the bypass was 
completed would be local rather than through traffic. The actual effects of the bypass, five years after its completion, are discussed below.

\section{Data Sources}

The impact of the bypass on the Cranberry Highway's traffic flow was determined using traffic count figures calculated by the Massachusetts Department of Public Works and the Southeastern Regional Planning and Economic Development District. The Cape Cod Planning and Economic Development Commission supplied the numbers for Route 28 in Yarmouth. When necessary, the raw numbers were converted into percentages to allow for more effective comparisons.

Analysis

The effects on traffic counts were felt immediately upon the bypass' opening on August 11, 1987. Weekday traffic declined by over sixty-two percent, Saturday by almost sixty percent, and Sunday by slightly more than fifty percent (Table 3-1). Although the decrease in traffic was not seventy-percent as predicted, the change was substantial. The total drop in traffic per week was almost fifty-eight percent. This is a large amount considering it occurred within the time span of one month.

Comparing the average daily traffic for Route $6 / 28$ at the Bourne/Wareham line and Route 28 in Yarmouth at the Barnstable/Yarmouth town line for three recent years provides further insight. 
Table 3-1

PERCENT CHANGE IN TRAFFIC COUNTS

ON THE CRANBERRY HIGHWAY BEFORE

AND AFTER BYPASS OPENING

\begin{tabular}{|c|c|c|c|}
\hline $\begin{array}{c}\text { Combined } \\
\text { Traffic Count }\end{array}$ & $\begin{array}{c}\text { Pre-Opening } \\
\text { July, 1987 }\end{array}$ & $\begin{array}{c}\text { Post-Opening } \\
\text { August, 1987 }\end{array}$ & $\begin{array}{c}\text { Percent } \\
\text { Change }\end{array}$ \\
\hline Weekday & 56,570 & 21,420 & -62.1 \\
\hline Saturday & 61,210 & 24,540 & -59.9 \\
\hline Sunday & 53,000 & 26,230 & -50.5 \\
\hline Weekly Total & 170,780 & 72,190 & -57.7 \\
\hline
\end{tabular}

Source: Southeastern Regional Planning and Economic Development District.

Between 1986 and 1988, traffic on the Cranberry Highway dropped by fiftyfive percent, while on Route 28 in Yarmouth the decline was twenty-eight percent (Table 3-2). The twenty-seven percentage points difference between the two figures may be attributable to the bypass. Another reason for the difference may be due to high levels of traffic travelling on the Cranberry Highway.

The Cranberry Highway has higher traffic counts than the control area: the mean average daily traffic for the three years combined was 25,583 on the Cranberry Highway and 16,681 in Yarmouth. The Cranberry Highway's average traffic volume is thirty-five percent higher than the volume on Route 28 in Yarmouth. Such high traffic counts may be more volatile and tend to fluctuate more than those of Route 28 in Yarmouth. In this case the bypass would have had little or no effect. 
Table 3-2

WAREHAM AND YARMOUTH TRAFFIC COUNTS

ROUTE 6/28 AT BOURNE TOWN LINE AND

ROUTE 28 AT BARNSTABLE TOWN LINE

1986-1989

\begin{tabular}{||c|c|c|c|c||}
\hline \multirow{3}{*}{ YEAR } & \multicolumn{2}{|c|}{ CRANBERRY HIGHWAY } & \multicolumn{2}{c||}{ ROUTE 28/YARMOUTH } \\
\cline { 2 - 5 } & $\begin{array}{c}\text { AVERAGE } \\
\text { DAILY } \\
\text { TRAFFIC }\end{array}$ & $\begin{array}{c}\text { PERCENT } \\
\text { CHANGE }\end{array}$ & $\begin{array}{c}\text { AVERAGE } \\
\text { DAILY } \\
\text { TRAFFIC }\end{array}$ & $\begin{array}{c}\text { PERCENT } \\
\text { CHANGE }\end{array}$ \\
\hline 1986 & 38,750 & NA & 20,170 & NA \\
\hline 1988 & 17,300 & -55 & 14,529 & -28 \\
\hline 1989 & 20,700 & +20 & 15,343 & +6 \\
\hline
\end{tabular}

Source: Southeastern Regional Planning and Economic Development District and Cape Cod Planning and Economic Development Commission

From 1988 to 1989 , traffic on the Cranberry Highway increased twenty percent while Route 28 in Yarmouth's increase was only six percent (Figure 3-1). The fourteen-percentage point difference may be attributed to an increase in year-round local traffic and business, or it might be a result of fluctuations in traffic volume.

Summary

Traffic counts on the Cranberry Highway dropped considerably after the Route 25 bypass was completed. Within the time span of one month, average weekly traffic dropped approximately fifty-seven percent. Although traffic counts for both the Cranberry Highway and Route 28 in Yarmouth decreased from 1986 to 1988 , the decline on the Cranberry Highway was twenty-seven percentage points more than Route 28 in Yarmouth. This difference may be 
FIGURE 3-1

COMPARISON OF TRAFFIC COUNTS

ROUTE 28 IN WAREHAM AND YARMOUTH

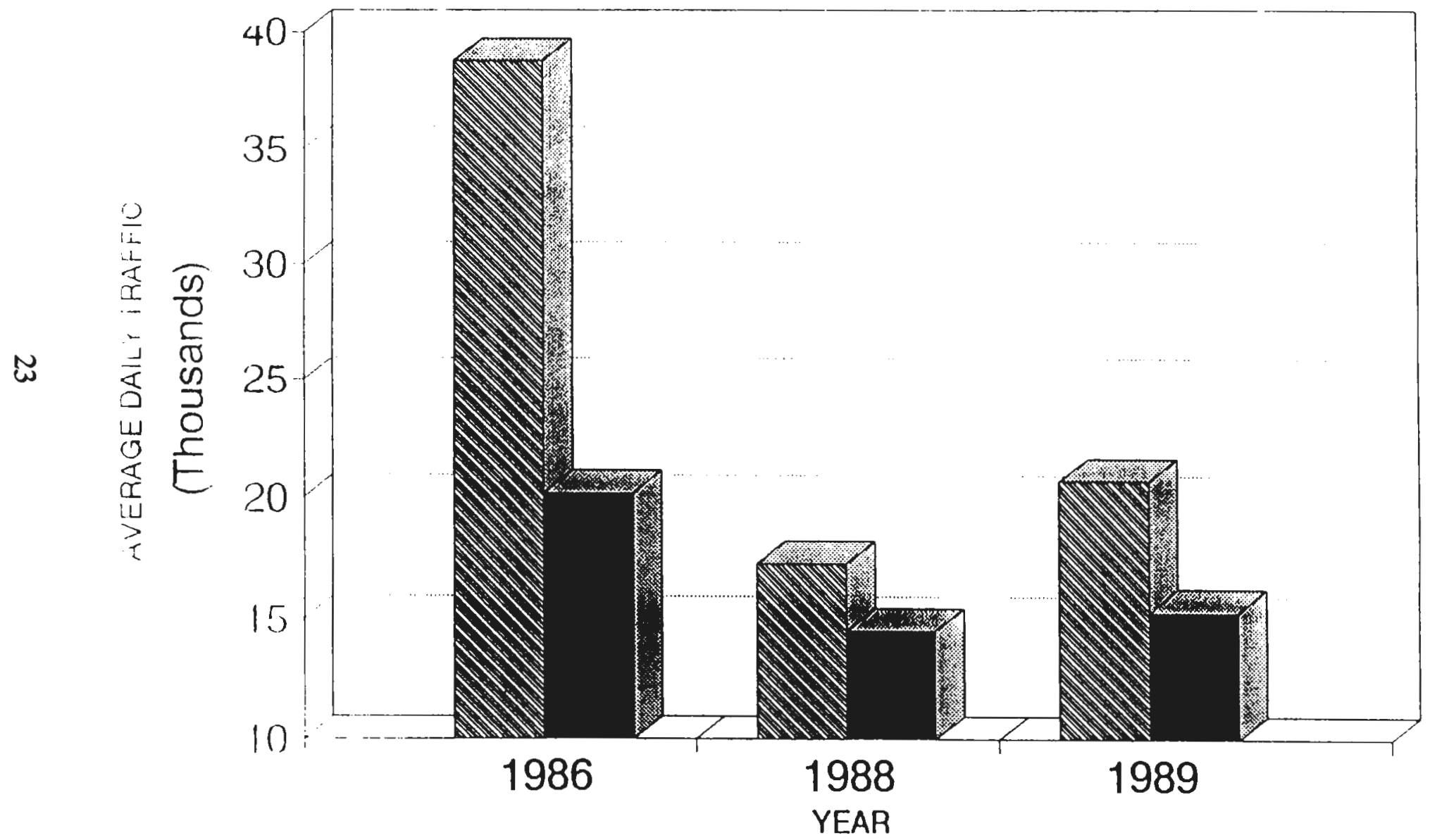

WAREHAM YARMOUTH

Sources: Southeastern Regional Planning and Economic Development District and Cape Cod Planning and Economic Development Commission. 
attributed to the bypass or to normal fluctuations in traffic counts due to high traffic volume on the highway. A fourteen percentage point discrepancy from 1988 to 1989 may have been the result of increased local traffic on the Cranberry Highway or, once again, fluctuations in traffic counts. 
CHAPTER FOUR BUSINESS 


\section{CHAPTER FOUR}

\section{BUSINESS}

\section{Introduction}

Many people automatically assume a bypass will be detrimental for businesses being bypassed. The case studies discussed in Chapter Two contradict this conventional wisdom. Some businesses will be hurt, usually those highly dependent on through traffic. Others that can cater to local trade frequently experience positive effects on their sales receipts. According to Grotewald and Grotewald (1958: 236):

Most studies have revealed that sales to through travelers make up a much smaller portion of a community's total business activity than is commonly supposed. Grocery stores, auto repair shops, and taverns depend almost entirely on regular customers who live an work within five miles. Even the gas stations, restaurants, and drive-in snack bars cater to a large extent to nearby residents.

According to the U.S. Department of Commerce (1964c:93) several factors determine whether a bypass will adversely affect retail trade. These are: (1) the nature of the business (whether it is highway-oriented or local-oriented), (2) the traffic volume and rate of economic growth after the bypass, (3) physical features like distance and visibility from the bypass, (4) adjustments made by the business establishment or community groups to bypass conditions (e.g. roadside advertising or reorientation towards locally oriented traffic).

A highway-oriented business can adapt to changing conditions after a bypass in several ways. Usually this involves modifying the business to a more localorientation. For example, a fast food restaurant can become to a family restaurant, a souvenir or gift shop may become a variety store or hardware store, a gas station 
could emphasize service and repair rather than only gas, and a motel could covert its units into apartments (Allen and McElyea 1958: 151-152).

The population size of a town can have an effect on how well the businesses in town are able to adapt to bypass conditions. According to Horwood, Zellner, and Ludwig (1965: 14) "towns over 5,000 people will have a somewhat better chance of adjusting to the economic changes induced by a bypass". This is supported by the theory of central places, which states that larger towns will have a more diversified market and serve a larger and more dispersed population. Businesses in a small town may narrowly specialize and would be more likely to be harmed by a bypass.

Central Place Theory. The theory of central places was conceived by the German geographer Walter Christaller. Christaller claimed that producers tended to cluster together at locations called central places. The central place system is a hierarchy ranked according to population size and market area of businesses (Dicken and Lloyd, 1990a: 25).

Many studies of central place systems have tried to establish a functional relationship between the number of central functions, or the number of establishments of each functional type, and population. Theoretically, areas with large populations will support more central functions than areas with smaller populations. Seven studies carried out in diverse areas found "each level in the hierarchies of the seven areas is also associated with a particular population size or range of population sizes (Dicken and Lloyd, 1990b: 39). 
TABLE 4-1

\section{GAIN OR LOSS IN RETAIL SALES \\ IN BYPASSED TOWNS, BY \\ POPULATION SIZE}

\begin{tabular}{||l|c|c||}
\hline $\begin{array}{c}\text { Population } \\
\text { Size }\end{array}$ & $\begin{array}{c}\text { Towns having } \\
\text { gains in sales }\end{array}$ & $\begin{array}{c}\text { Towns } \\
\text { having } \\
\text { losses in sales }\end{array}$ \\
\cline { 2 - 3 } & Number & Number \\
\hline Less than 5,000 & 16 & 1 \\
\hline 5,000 - 25,000 & 17 & 2 \\
\hline Over 25,000 & 0 & 1 \\
\hline Total & 33 & 4 \\
\hline
\end{tabular}

Source: Garrison and Marts (1958c), Table 6.

Table 4-1 summarizes the findings reported in thirty-seven studies on the effects of a bypass on retail sales by population-size. These results contradict the predictions from central place theory and Horwood, Zellner, and Ludwig's claim that towns over 5,000 people are more likely to recover from a bypass. In towns with 5,000 people or less, ninety-four percent of businesses experienced gains in sales. For towns with populations from 5,000 to 25,000 people, eighty-eight percent of businesses gained in sales. Regardless of these figures, theory supports the idea that an area with a large population stands a better chance of recovering from a bypass than an area with a small population. 
Gains and losses of businesses are further broken down by highway-oriented and non-highway oriented businesses in Table 4-2. Highway-oriented businesses include services stations, restaurants, and motels. All other businesses are classified as nonhighway oriented businesses. In each category, the total gains exceed total losses. Nonhighway-oriented businesses suffered the least losses. Some businesses do suffer as a result of a bypass, especially those that are traffic dependent. However, even if some businesses experience losses, a town's overall sales may increase and compensate for the losses. This raises the issue of distribution and equity. Some businesses lose out while more businesses benefit and the question of whether the many businesses that benefit are more important than the few than do not is raised.

\section{Data Sources}

Data for the Cranberry Highway for 1984 come from the Cranberry Highway Planning Project (1985), and 1992 data are from the Wareham Community Development Authority (1992). For Yarmouth, 1984 data are from assessor's records while 1992 are from the Yarmouth Police Department. The assessor's office keeps a list according to parcel numbers. Rather than stating specifically the type of land use, the list classifies parcel uses in a vague manner (e.g. retail, vacant, office, residential, etc.). Also, it is common for several uses to exist on a single lot, and the data do not identify such multiple usss. Since the 1984 data are so imprecise, reliable counts of businesses by type are impossible. 
TABLE 4-2

NUMBER OF BYPASSED TOWNS HAVING GAINS AND LOSSES IN RETAIL SALES FOR HIGHWAY AND NONHIGHWAY-ORIENTED BUSINESS, BY POPULATION SIZE

\begin{tabular}{|c|c|c|c|c|c|c|c|c|}
\hline \multirow{3}{*}{$\begin{array}{l}\text { Population size } \\
\text { of town }\end{array}$} & \multicolumn{6}{|c|}{ Highway-oriented business } & \multirow{2}{*}{\multicolumn{2}{|c|}{$\begin{array}{c}\text { Nonhighway- } \\
\text { oriented } \\
\text { business }\end{array}$}} \\
\hline & \multicolumn{2}{|c|}{ Service Stations } & \multicolumn{2}{|c|}{ Restaurants } & \multicolumn{2}{|c|}{ Motels } & & \\
\hline & Gains & Losses & Gains & Losses & Gains & Losses & Gains & Losses \\
\hline Less than 5,000 & 5 & 3 & 3 & 0 & NA & NA & 10 & 2 \\
\hline 5,000 to 25,000 & 13 & 8 & 11 & 8 & 8 & 3 & 6 & 1 \\
\hline Over 25,000 & NA & 0 & 1 & 0 & 1 & 0 & 1 & $\mathbf{0}$ \\
\hline TOTAL & 18 & 11 & 15 & 8 & 9 & 3 & 17 & 3 \\
\hline
\end{tabular}

NA-Not Available

Source: Garrison and Marts (1958d), Table 7. 
Analysis

The number of businesses in existence prior to the bypass were counted and compared to the number of businesses present in 1992. Also, businesses were classified into highway and non highway-orientated. According to the 1990 Census, Wareham's year round population is 19,232 . Wareham therefore stands a good chance of overcoming the problems of the bypass because its population is over 5,000 people. In fact, the commercial strip on the Cranberry Highway recovered and prospered since the bypass was built. In 1984, there were 138 business in operation on the Cranberry Highway. This rose approximately fifteen percent to 158 businesses in 1992. As expected, businesses became more oriented to local trade (Table 4-3). The total decrease in highway-oriented business was thirty percent. The sharpest drop was for amusement and recreation facilities (43\%) and fast food restaurants $(42 \%)$.

In Yarmouth fifty businesses, or thirty-seven percent, of the one hundred thirty-five businesses today, are highway-oriented. Motels represent over half of the highway-oriented businesses, reflecting the area's popularity with tourists. These twenty-seven motels are located within the three mile study area, but the highway extends at least ten more miles to the next town. Along the additional ten mile stretch of highway there are many more motels and other highway-oriented businesses. 
TABLE 4-3

HIGHWAY-ORIENTED BUSINESSES ON THE CRANBERRY HIGHWAY AND ROUTE 28 IN YARMOUTH

1984-1992

జ

\begin{tabular}{||l|c|c|c|c|c|c||}
\hline \multirow{2}{*}{\multicolumn{1}{c|}{ TYPE OF BUSINESS }} & \multicolumn{2}{c|}{1984} & \multicolumn{2}{c||}{1992} & \multicolumn{2}{c||}{ PERCENT CHANGE } \\
\cline { 2 - 8 } & WAREHAM & YARMOUTH & WAREHAM & YARMOUTH & WAREHAM & YARMOUTH \\
\hline Gift and Souvenir Shops & 14 & NA & 10 & 5 & -28 & NA \\
\hline Fast Food Restaurants & 12 & NA & 7 & 7 & -42 & NA \\
\hline Motels & 7 & NA & 6 & 27 & -14 & NA \\
\hline Amusement, Recreation & 7 & NA & 4 & 8 & -43 & NA \\
\hline Gas Stations & 7 & NA & 6 & 3 & -14 & NA \\
\hline Total & 47 & NA & 33 & 50 & -30 & NA \\
\hline
\end{tabular}

Sources: Computed from Cranberry Highway Planning Project (1985), Wareham Community Development Authority (1992), and Yarmouth Police Department Business Inventory (1992). 
The control area in Yarmouth now has approximately the same number of businesses that were present on the Cranberry Highway in 1984. Since 1984 there has been an increase of twenty businesses on the Cranberry Highway. There may be several reasons why Yarmouth has fewer businesses on a stretch of highway the same length as the Cranberry Highway. The first is lot sizes along the two highways. The numerous motels along Route 28 in Yarmouth occupy much more land area than do the other types of highway-oriented businesses more frequently found on the Cranberry Highway. As a result the Cranberry Highway is more densely developed than the strip in Yarmouth. The second reason may be related to traffic. The higher daily traffic for the Cranberry Highway may imply Wareham is a better place for business. And finally, the Cranberry Highway has experienced growth in the past eight years. Since 1984 twenty additional businesses have opened on the Cranberry Highway, some of which may be attributed to the bypass. Unfortunately, the imprecision in Yarmouth's 1984 assessor's records preclude valid examination of changes in Yarmouth's business composition.

\section{Summary}

This analysis supports the case studies cited in Chapter Two in that bypasses are usually beneficial for most businesses being bypassed. Highway-oriented businesses are most vulnerable to the change induced by bypasses.

The number of businesses on the Cranberry Highway in 1984 increased fifteen percent as of 1992. There may be several reasons why the Cranberry Highway has recovered from the bypass: (1) the businesses successfully shifted from highway- 
oriented to non-highway oriented, (2) the traffic volume remaining on the highway is sufficient to support some highway-oriented business, (3) the population living within the market area of the businesses is large enough to maintain most businesses. The third reason supports the theory of central places. 


\section{CHAPTER FIVE}

LAND VALUE 


\section{CHAPTER FIVE \\ LAND VALUE}

\section{Introduction}

The theory of land rent predicts that as access increases, land value will also increase. A change in the transportation system (e.g. a bypass) usually results in a change in the level of access in the area.

Location and access are synonymous in a static framework, but may differ over time. Access is the effective nearness to all other activities or those of interest, and location is a geographic point. As long as nothing else changes, a change in access for a firm means a change in location. If, however, the locations of other firms or features of the transportation system change, the access of the firm is changed without moving its location (Lee and Yujnovsky 1971a: 15)

Although the location of businesses on the Cranberry Highway have not changed, the locational characteristics have. Through travellers no longer need to pass through Wareham on the Cranberry Highway, and as a result there has been a shift in relative access (Lee and Yujnovsky 1971b: 1). In a sense access has been reduced for through travellers. However, another change in access, an increase in relative access, has occurred because the Cranberry Highway is now more accessible to local traffic. This shift in access was most likely to the advantage of most local businesses because through traffic usually generates little business for retailers (Bowden 1967: 37).

Access is a major determinant of land value or rent (Lee and Yujnovsky 1971c: 1). A positive shift in relative access usually results in a positive change in land values. Location rent for a unit of land varies with access to its market. The 
more accessible a parcel of land is to a given market, the more desirable it is. If access increases, then the location rent (or land values) should also increase (Dicken and Lloyd 1990c: 53). On the Cranberry Highway there was an overall increase in relative access for local residents after the bypass. Essentially, the local market became more accessible in Wareham by increasing accessibility to the Cranberry Highway. The theory of location rent predicts land values increase in such circumstances. ${ }^{1}$

\section{Methods and Procedures}

Land values were computed using property sales records obtained through the assessor's office in both Wareham and Yarmouth. Data on sales of vacant land within the study areas were compiled for 1986 through 1990. The prices paid for lots were divided by the consumer price index for that year to adjust to inflation. These figures were divided by the lot's square footage to obtain the price per square foot, which were then averaged by year. The figures for each year were compared by town. ${ }^{2}$

${ }^{1}$ The theory of land rent discussed here is based on neo-classical theory. There are other schools of thought that were not applied.

${ }^{2}$ These calculations are in the Appendix. 
Analysis

In 1987 , the average price per square foot plummeted from $\$ 2.17$ to $\$ 0.70$ on the Cranberry Highway. The bypass was opened on August 11, 1987 and anticipation of the event may have negatively affected land values. The other years had no similar sharp changes in land values. In fact 1986, 1988, and 1989 prices varied by only forty-five cents per square foot. A gradual increase in land values occurred from 1986 to 1988 on Route 28 in Yarmouth. In 1989 the price per square foot plunged from $\$ 3.34$ to $\$ 1.11$, and it continued to drop to $\$ 0.84$ in 1990 . This drop coincides with the beginning of a recession that was particularly severe in New England.

The average price per square foot in the two study areas behaved very differently from 1986 to 1990 (Figure 5-1). The recession, which began in 1988, seems to have had a major impact on average prices in Yarmouth. As mentioned earlier, from 1986 to 1988 the price increased. However, between 1988 and 1989 prices decreased by sixty-seven percent. This decrease continued, albeit more gradually, in 1990. On the opposite end of the spectrum, Wareham's average price per square foot plunged in 1987, most likely in response to the bypass. However, there was a full recovery in 1988, a slight increase in 1989 , and a ten percent decrease in 1990 . The results of this analysis may have been affected by the small number of cases. The number of cases used in calculating average price per square foot ranged from two to five and may not have allowed a precise measure of land value. 
FIGURE 5-1

PROPERTY SALES IN WAREHAM AND YARMOUTH AVERAGE PRICE PER SQUARE FOOT

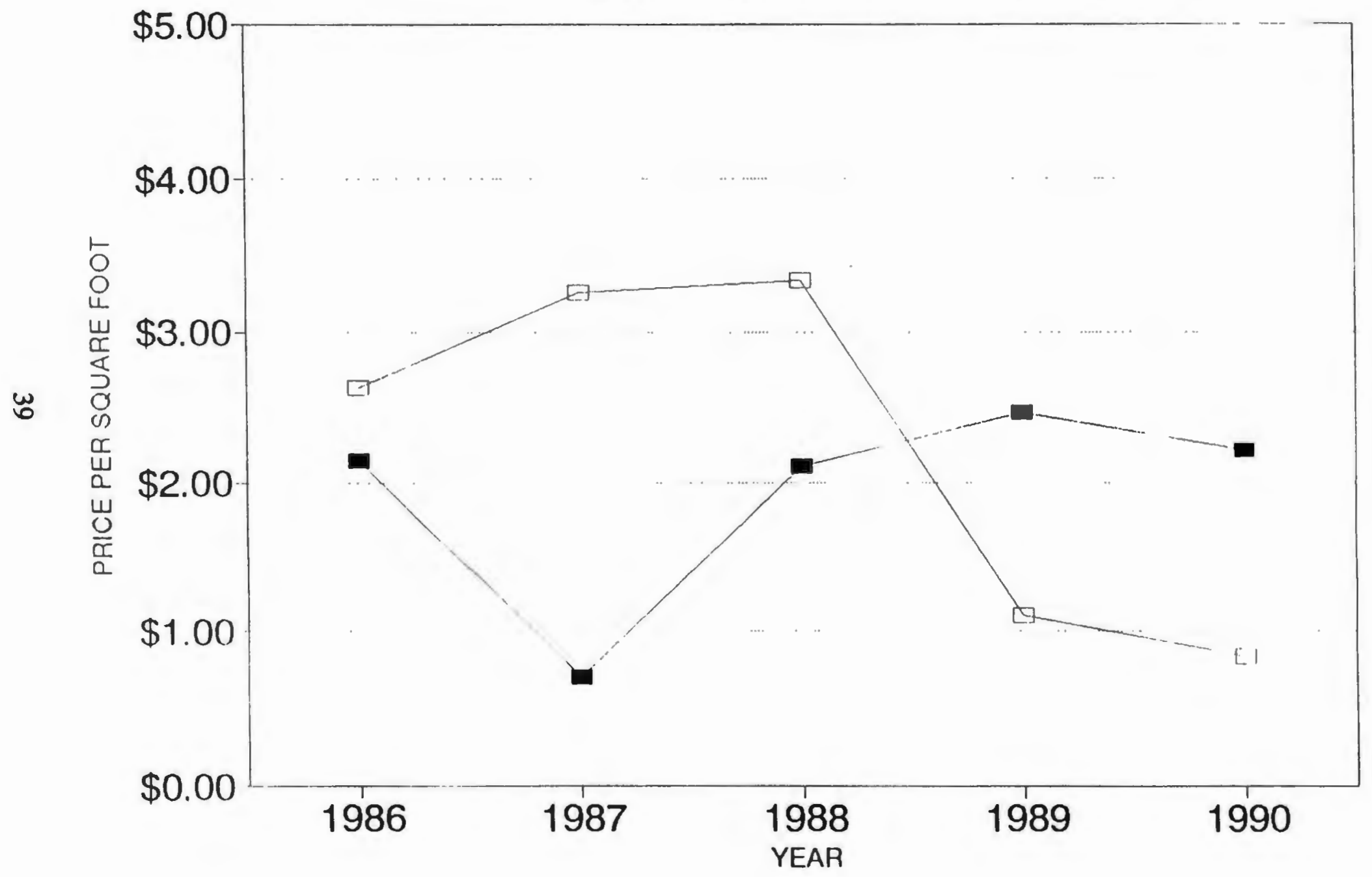

- WAREHAM - $\square$ YARMOUTH

Source: Property Sales Records, towns of Wareham and Yarmouth Assessor's Office 


\section{Summary}

A highway improvement or change in infrastructure usually has an impact on land values. A positive shift in relative access tends to increase land values, while a decrease negatively affects land values. The Cranberry Highway bypass decreased the friction of travel for local residents, which in turn stimulated more local trade.

The bypass may have mitigated the impacts of the recession for the Cranberry Highway by acting as a catalyst for increased land values. The area along the Cranberry Highway saw little change in land values from 1986 to 1990, with the exception of 1987. This drastic drop was most likely a result of anticipation of the bypass. Land values along Route 28 in Yarmouth decreased after 1989. This may reflect the regional recession. 
CHAPTER SIX CONCLUSION 


\section{CHAPTER SIX \\ CONCLUSION}

\section{Suggestions for Further Research}

The methods used to determine the effects of the Route 25 bypass are just a few of many to choose from. Some methods were not used because of time or data limitations, while others were not applicable.

When looking at a bypass' effect on business, sales figures may be used in addition to the number of businesses present before and after the bypass. Sales figures give a more complete representation of the business climate than the number of businesses. The number of businesses may increase after a bypass, while the total sales for these businesses may be less than the total sales for the number of businesses prior to the bypass. This information provides a tangible understanding of the effects of a bypass on businesses.

Seasonal variations may also be taken into consideration. It would be interesting to learn whether the Cranberry Highway's average daily traffic for the winter has actually increased since the bypass. There are more local-oriented businesses along the highway now, and local traffic in the winter may have increased due to the bypass. The data on traffic counts were computed, by regional planning agencies on an annual basis, using transportation forecasting formulas. Unfortunately, these data could not be disaggregated to determine seasonal variations. 
Further research on impacts of bypasses may focus on the relationship between central place theory and the effect on business. As mentioned previously, the logic of this theory indicates that areas serving large populations will stand a good chance of benefitting from a bypass. It would be interesting to delve further and to research the relationship between population size and bypass impacts.

\section{Summary}

The purpose of this research project is to assess the effects of the Route 25 bypass on the Cranberry Highway. The project examines and measures impacts on traffic, local business, and traffic.

The most important finding is that, contrary to popular belief, bypasses are generally not harmful to the overall business climate of the area being bypassed. On the Cranberry Highway, the number of businesses increased fifteen percent since the opening of the bypass. The gain in the number of businesses is due to a decrease in traffic congestion which, in turn, increased local trade. Not all businesses benefitted from the bypass. Those that did suffer were dependent on through traffic, such as fast food restaurants, gas stations, amusement and recreation, and motels.

Traffic has declined on the Cranberry Highway by approximately fifty percent. The reduction in traffic has allowed local trade to prosper since the bypass. Prior to the bypass, local residents would avoid the Cranberry Highway and as a result they would not patronize most businesses along it. Since through traffic was bypassed, local residents are more willing to travel on the highway and to shop at highway businesses. 
Land values on the Cranberry Highway did not suffer negative impacts from the bypass, with the possible exception of 1987. The bypass was opened in 1987, and it is possible that anticipation of negative consequences resulting from the bypass may be the reason land values declined. However, by 1988 average land values on the Cranberry Highway had increased over 1986 average values, whereas land values in the control area declined over the same period. This may reflect the effects of the regional recession in Yarmouth, while the bypass mitigated similar negative effects on the Cranberry Highway. 


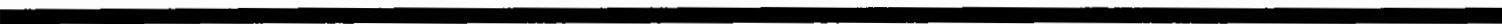

APPENDIX 
TABLE A-1

CRANBERRY HIGHWAY PROPERTY SALES 1986-1990

\begin{tabular}{|c|c|c|c|c|c|}
\hline DATE & $\begin{array}{l}\text { SALE } \\
\text { PRICE }\end{array}$ & $\begin{array}{l}\text { CONSUMER } \\
\text { PRICE INDEX }\end{array}$ & $\begin{array}{l}\text { SALE PRICE IN } \\
1982 \text { DOLLARS }\end{array}$ & $\begin{array}{l}\text { SQUARE } \\
\text { FEET }\end{array}$ & $\begin{array}{l}\text { PRICE PEF } \\
\text { SQ. FT. }\end{array}$ \\
\hline $01 / 29 / 86$ & 21000 & 1.36 & 15441.17647 & 3060 & 5.05 \\
\hline $04 / 29 / 86$ & 80000 & 1.36 & 58823.52941 & 36000 & 1.63 \\
\hline $07 / 10 / 86$ & 475000 & 1.36 & 349264.7059 & 234788 & 1.49 \\
\hline $12 / 31 / 86$ & 1200000 & 1.36 & 882352.9412 & 2278624 & 0.39 \\
\hline TOTAL & 1776000 & & 1305882.353 & 2552472 & 8.55 \\
\hline AVERAGE & 444000 & & 326470.5 & 638118 & 2.14 \\
\hline $01 / 08 / 87$ & 20000 & 1.44 & 13888.88889 & 30693 & 0.45 \\
\hline $01 / 12 / 87$ & 18700 & 1.44 & 12986.11111 & 12464 & 1.04 \\
\hline $03 / 05 / 87$ & 10000 & 1.44 & 6944.444444 & 11440 & 0.61 \\
\hline TOTAL & 48700 & & 33819.44444 & 54597 & 2.10 \\
\hline AVERAGE & 16233 & & 11273.15 & 18199 & 0.7 \\
\hline $08 / 19 / 88$ & 200000 & 1.54 & 129870.1299 & 42780 & 3.04 \\
\hline $09 / 28 / 88$ & 163500 & 1.54 & 106168.8312 & 48793 & 2.18 \\
\hline $12 / 16 / 88$ & 127500 & 1.54 & 82792.20779 & 101495 & 0.82 \\
\hline TOTAL & 491000 & & 318831.1688 & 193068 & 6.03 \\
\hline AVERAGE & 163667 & & 106277.07 & 64356 & 2.01 \\
\hline $02 / 14 / 89$ & 220000 & 1.63 & 134969.3252 & 140699 & 0.96 \\
\hline $04 / 03 / 89$ & 120000 & 1.63 & 73619.6319 & 48352 & 1.52 \\
\hline $04 / 24 / 89$ & 100000 & 1.63 & 61349.69325 & 12500 & 4.91 \\
\hline TOTAL & 440000 & & 269938.6503 & 201551 & 7.39 \\
\hline AVERAGE & 146667 & & 89979.367 & 67184 & 2.46 \\
\hline $02 / 05 / 90$ & 120000 & 1.69 & 71005.91716 & 21010 & 3.38 \\
\hline $12 / 13 / 90$ & 85000 & 1.69 & 50295.85799 & 48793 & 1.03 \\
\hline TOTAL & 205000 & & 121301.7751 & 69803 & 4.41 \\
\hline AVERAGE & 102500 & & 60653.9 & 34902 & 2.21 \\
\hline
\end{tabular}

* Note: Consumer Price Index is based on 1982 dollars.

Source: Property sales records. Lown of Wareham Assessor's Office 
TABLE A-2

ROUTE 28 IN YARMOUTH PROPERTY SALES

1986-1990

\begin{tabular}{|c|c|c|c|c|c|}
\hline DATE & $\begin{array}{l}\text { SALE } \\
\text { PRICE }\end{array}$ & $\begin{array}{l}\text { CONSUMER } \\
\text { PRICE INDEX }\end{array}$ & $\begin{array}{l}\text { PRICE IN } \\
1982 \text { DOLLARS }\end{array}$ & $\begin{array}{l}\text { SQUARE } \\
\text { FEET }\end{array}$ & $\begin{array}{l}\text { PRICE PER } \\
\text { SQ.FT. }\end{array}$ \\
\hline $11 / 06 / 86$ & 94624 & 1.36 & 69576.470588 & 287496 & 0.24 \\
\hline $12 / 18 / 86$ & 200000 & 1.36 & 147058.82353 & 29185 & 5.04 \\
\hline TOTAL & 294624 & & 216635.29412 & 316681 & 5.28 \\
\hline AVERAGE & 147312 & & 108317.65 & 158341 & 2.64 \\
\hline $02 / 27 / 87$ & 100000 & 1.44 & 69444.444444 & 96268 & 0.72 \\
\hline $05 / 01 / 87$ & 320000 & 1.44 & 222222.22222 & 34848 & 6.38 \\
\hline $11 / 06 / 87$ & 50000 & 1.44 & 34722.222222 & 10019 & 3.47 \\
\hline $12 / 18 / 87$ & 125000 & 1.44 & 86805.555556 & 34848 & 2.49 \\
\hline TOTAL & 595000 & & 413194.44444 & 175983 & 13.05 \\
\hline AVERAGE & 148750 & & 103298.6 & 43996 & 3.26 \\
\hline $02 / 08 / 88$ & 75000 & 1.54 & 48701.298701 & 11326 & 4.30 \\
\hline $03 / 10 / 88$ & 50000 & 1.54 & 32467.532468 & 20909 & 1.55 \\
\hline $04 / 15 / 88$ & 90000 & 1.54 & 58441.558442 & 14375 & 4.07 \\
\hline $07 / 15 / 88$ & 60000 & 1.54 & 38961.038961 & 12197 & 3.19 \\
\hline $09 / 28 / 88$ & 370000 & 1.54 & 240259.74026 & 66647 & 3.60 \\
\hline TOTAL & 645000 & & 418831.16883 & 125454 & 16.72 \\
\hline AVERAGE & 129000 & & 83766.24 & 25091 & 3.34 \\
\hline $02 / 01 / 89$ & 42500 & 1.63 & 26073.619632 & 69696 & 0.37 \\
\hline $06 / 30 / 89$ & 400000 & 1.63 & 245398.77301 & 184694 & 1.33 \\
\hline $10 / 06 / 89$ & 255000 & 1.63 & 156441.71779 & 96268 & 1.63 \\
\hline TOTAL & 697500 & & 427914.11043 & 350658 & 3.33 \\
\hline AVERAGE & 232500 & & 142638.03 & 450219 & 1.11 \\
\hline $01 / 16 / 90$ & 54500 & 1.69 & 32248.52071 & 80586 & 0.40 \\
\hline $06 / 29 / 90$ & 99000 & 1.69 & 58579.881657 & 46174 & 1.27 \\
\hline TOTAL & 153500 & & 90828.402367 & 126760 & 1.67 \\
\hline AVERAGE & 76750 & & 45414.2 & 63380 & 0.84 \\
\hline
\end{tabular}

-Nole: Consumer Price Index is based on 1982 dollars.

Source: Property sales records, town of Yarmouth Assessor's Office 


\section{REFERENCES}




\section{REFERENCES}

Allen, J. K, and Richard McElyea. 1958. Impact of improved highways on the economy of the United States. Stanford: Stanford Research Institute.

Bowden, Martyn J. 1968. Expressway and the town: The growth of Oxford, Massachusetts, 1955-1985, before and after the completion of Highway 52. Worcester: Department of Geography, Clark University.

Buffington, Jesse L. (1967). A study of the economic impact of Interstate Highway 45 on Conroe, Texas. Texas Transportation Institute Research Report No. 411. College Station: Texas A \& M. University.

Davey, Martha; Paige Holland; and Anthony Tenreiro. 1990. Functional area report on the town of Narragansett, Rhode Island. Kingston: Department of Community Planning and Area Development, University of Rhode Island.

Dicken, Peter and Peter E. Lloyd. 1990. Location in space: Theoretical perspectives in economic geography. New York: Harper \& Row.

Fales, Amy E. 1989. An analysis of the effects on business along the Cranberry Highway as a result of the Route 25 bypass. Department of Business Administration, Franklin Pierce College.

Garrison, William L. and Marion E. Marts. 1958. Geographic impact of highway improvement: Changes in transportation, land use, and business patterns concurrent with the reorientation of U.S. Highway 99 in the vicinity of Marysville, Washington. University of Washington Highway Economic Studies.

Garrison, William L. and Marion E. Marts. 1958. Influence of highway improvements on urban land: A graphic summary. University of Washington Highway Economic Studies.

Grotewald, Andreas and Lois Grotewald. 1958. Commercial development of highways in urbanized regions: A case study. Land Economics 34, 3 (August): 236-244. 
Horwood, Edgar M.; Carl A. Zellner; and Richard L. Ludwig. 1965. Community consequences of highway improvement. National Cooperative Highway Research Program Report 18. University of Washington.

Johnson, R.; F. Obermiller; and H. Radtre. 1989. The economic impact of tourism sales. Journal of Leisure Research 21, 2: 140-154.

Jorgenson, C. P. 1968. Long term economic effects of Highway SD 50 bypass on Tyndall, South Dakota. Pierre: South Dakota Department of Highways.

Lee, Douglas B., and Oscar Yujnovsky. 1971. Transportation and land use:

Research design for the analysis of BART impacts. Institute of Urban and Regional Development Working Paper No. 148/BART 2. Berkeley: University of California.

New England Telephone. 1991. Phone book for Falmouth calling area. Hyannis.

Ohio Department of Highways. 1966. A bypass economic impact study of Circleville, Piqua, and St. Clairsville, Ohio. Cincinnati

Smith, J. R. 1957. Roadside merchandising. California Highways and Public Works 36, 7-8 (July-August): 78-93.

Stover, Vergil G. and Frank J. Koepke. 1988. Transportation and land development. Englewood Cliffs: Prentice-Hall.

Southeastern Regional Planning and Economic Development District. The future of the Cranberry Highway: An economic analysis. Taunton, Massachusetts.

Southeastern Regional Planning and Economic Development District. 1985. Wareham Traffic Study: Route 6/28, I-495, and the Route 25 extension. Taunton, Massachusetts.

United States Department of Commerce, Bureau of the Census. 1990. Washington D.C.: U.S. Government Printing Office.

United States Department of Commerce, Office of Research and Development. 1964. Highways and economic and social changes. Washington D.C.: U.S Government Printing Office.

Utah State University. 1968. Economic and social effects of a highway bypass: American Fork, Utah. College of Business and Science: After Interstate Construction, 2. 
Vockrodt, Robert W. 1967. The economic effects of a highway change on Faribault, Minnesota. Minneapolis: University of Minnesota.

Wareham Community Development Department. 1985. Cranberry Highway Planning Project.

Young, W. S. 1951. Fairfield study. California Highways and Public Works 30, 1-2 (January-February): 1-5. 